\title{
Counts and cards - a novel way to detect typhoid infections in the ED
}

\author{
Pragya Mallick, Aditya Maddali, Tausif Thangalvadi, Parivalavan Rajavelu* \\ From International Summit on Emergency Medicine and Trauma 2014 \\ Puducherry, India. 12-16 February 2014
}

\section{Objective}

The diagnosis of typhoid fever is made by growth of the causative microorganism from culture of bone marrow aspirate or blood which is time dependent. In a busy ED like ours, typhoid fever is a frequent presentation. There is need for a rapid and reliable test made available at the bed side, to detect typhoid infections. The sensitivity and specificity of Enterocheck WB, a card test that detects IgM antibodies to salmonella typhi and low eosinophil counts were compared individually and together, with the gold standard of blood culture using BacT/Alert.

\section{Methods}

Setting - Multi specialty community based teaching hospital in Chennai with about $1500 \mathrm{ED}$ visits per month

Number of subjects - 95 .

Study design - Retrospective study done from January 2012 for a period of 1 year.

\section{Results}

For 4 or lesser days of fever, typhoid IgM had sensitivity of $66.67 \%$, specificity of $40 \%$. For 5 or greater days of fever, sensitivity was $75.61 \%$, specificity $50 \%$.

Eosinophil count was persistently low $(0.09 \%)$ in all Typhoid cases irrespective of day of presentation of fever.

Sensitivity of a low eosinophil count was $100 \%$, specificity being $14.8 \%$.

In all culture positive cases, sensitivity of IgM and low eosinophil counts together was $100 \%$. For all culture negative cases, specificity was $92.3 \%$. So both IgM and eosinophil count together have a high specificity as well as sensitivity.

\footnotetext{
* Correspondence: parivalavan@gmail.com

Sundaram Medical Foundation Dr Rangarajan Memorial Hospital, Shanthi Colony, Anna Nagar, Chennai, India
}

\section{SpringerOpen ${ }^{\circ}$}

(C) 2014 Mallick et al; licensee Springer This is an Open Access article distributed under the terms of the Creative Commons Attribution License (http://creativecommons.org/licenses/by/2.0), which permits unrestricted use, distribution, and reproduction in any medium, provided the original work is properly credited.

\section{Limitations}

This was a retrospective study. Prospective study is awaited to reconfirm the results.

\section{Conclusion}

The typhoid IgM test can be performed at the bedside in the ED. Eosinophil count can be easily obtained from a CBC. In conjunction, they can accurately detect salmonella infections for early initiation of appropriate treatment in the ED itself, thereby saving time, money and precious hospital beds.

Published: 25 July 2014

doi:10.1186/1865-1380-7-S1-P1

Cite this article as: Mallick et al:: Counts and cards - a novel way to detect typhoid infections in the ED. International Journal of Emergency Medicine 2014 7(Suppl 1):P1. journal and benefit from:

- Convenient online submission

- Rigorous peer review

- Immediate publication on acceptance

- Open access: articles freely available online

- High visibility within the field

Retaining the copyright to your article

Submit your next manuscript at $>$ springeropen.com
Submit your manuscript to a SpringerOpen ${ }^{\circ}$ 